Isaienko S.A., Hurinchuk S.V.

\title{
FORMATION OF VALUE ATTITUDE TO THE HUMANITARIAN COMPONENT OF PROFESSIONAL TRAINING AS A TASK OF HIGHER EDUCATION IN THE CONTEXT OF UKRAINE'S INTEGRATION INTO THE GLOBAL EDUCATIONAL SPACE
}

The issues of the formation of a professional, the features of the manifestation of a human person in his/her professional activity, the interconnection and interdependence of human life and the scope of his professional activity are extremely relevant in the 21 st century. The article analyzes the problem of forming the value attitude in students to the humanitarian component of professional training and professional culture of the personality of future specialists in engineering and technical profile at the present stage of development of higher professional education in Ukraine in the context of its integration into the global educational space. At the end of the twentieth century, it became customary to consider almost the only function of technical education - the training of a specialist capable of performing specific production tasks. However, modern production requires engineering and technical specialists to perform atypical functions in the past, requires a rethinking of many of the former and the creation of new world outlooks and values, without which the revival and existence of society is impossible. High-quality training of engineering workers cannot be limited to the purely technical cycle of training subjects. Life and modern production requires an engineer to have knowledge on social and humanitarian subjects, knowledge from areas related to engineering and technical training, computer technology, as well as knowledge of his/her native language and knowledge of foreign languages as well. The authors believe that one of the main tasks of the higher education system is purposeful work on the formation of a professional culture of future specialists, and the formation of a value-based attitude to the humanitarian aspects of life and professional activity is an integral part of this culture. However, professional culture is a complex multilateral construct, the formation of which begins on the university bench and continues throughout life. In the framework of professional training in a higher education institution, we can only talk about laying the foundations of such a personal construct. Consequently, the need to form a new social environment, to develop such priorities of social development, where the main element is the person himself, has become obvious and universally recognized in the world today.

Keywords: value attitude, humanitarian component of professional training, professional culture of a specialist, activity, axiological and cultural studies approaches, personality-oriented model of higher education, professional training

Statement of the problem. The integration of the higher education system of Ukraine into the global and European educational space forms a social order for new approaches to assessing the quality of professional training of specialists, objectively determines the application of modern didactic concepts aimed at training highly qualified professionals and creative professionals in the educational process. Dynamic changes in the Ukrainian society, generated by the processes of globalization, integration and diversification in the world, have actualized the problem of qualitative training of professional cadres of the country, since it is for them in the realities of life today to make optimal decisions to ensure the progress of domestic scientific researches and development. Among the problems that the high school faced in the period of social reform is the problem of forming the humanistic orientation of the future specialist personality, his/her value markers.

In accordance with the tradition in Ukraine, higher education is not only a centre of science and education, but also a factor in the reproduction of the spiritual life of a society. However, the tendency of professionalization of higher education has led to the erosion of the whole cultural stratum in the education of specialists, facilitated the development of students with narrow professional thinking. In the second half of the twentieth century, awareness and elimination of the 
negative consequences of development in conditions of self-isolation and excessive ideologization, active study of the world level of human and social sciences led the national system of higher education to the need to revise the goals, content, forms, methods of teaching and perception of humanitarian subjects. The powerful impetus for the humanization and humanitarization of higher education was given by the processes of state formation in Ukraine. The foundations of the humanization of education were laid down in the normative documents that defined the directions of higher education reform in the 1990s. The humanistic approach is seen as the possibility of overcoming the basic error of the previous period - impersonation.

Analysis of recent research and publications. Theoretical and methodological foundations and practical experience of forming a valuable attitude towards the humanitarian component of professional training of future specialists and the culture of students' personality are reflected in the scientific achievements of foreign and domestic educators, such as Paryzhnyi, Yu. (1992), Honcharenko, S. (1995), Habovych, O. (2001), Savelev, A. (2001), Skliar, P.; Umanska, T. (2007), Andrushchenko, V. (2012) and many others. The humanities of higher engineering education were raised in the works of Kurhuzov, V. (1997), Dobruskyn, M. (2000), Chystovska, I. (2008). However, both the general theoretical questions of the humanitarization of the higher technical school and the practical-applied issues of formation of value attitude to the humanitarian component of professional training of modern specialists are lacking in development.

The purpose of the study is to substantiate organizational and pedagogical approaches to the formation in students of engineering and technical specialties value attitude to the humanitarian component of their professional training.

The main results of the study. Our analysis of the current educational situation in Ukraine from the point of view of reform shows that a social order for a new approach to the professional training of future specialists has been clearly formed in the society. At the end of the twentieth century, the higher technical school was influenced by economic and social instability in society, problems of environmental imbalance and negligent attitude to the environment, increased technocratic tendencies of scientific and technological progress and lack of spirituality and education of the specialist. This influence, in turn, has led to a considerable deformation of the understanding of the tasks that the higher technical school should solve. It has become customary to consider the only function of technical education to be the training of a "narrow" specialist capable of performing specific production tasks, rather than the formation of a highly educated person, whose main role in life is played by human values and priorities, rather than a career or production plan. However, modern manufacturing requires engineering specialists to perform atypical functions in the past, requires rethinking many of the past and creating new worldviews and values, without which the revival and existence of our society is impossible. Therefore, the need to create a new social environment, to develop such priorities of social development, where the main element is the person himself, has become evident and widely recognized today.

Awareness of the need for a fundamentally new quality of preparation of a specialist for his future professional activity in a society in which knowledge becomes a major factor of economic growth, in Ukraine was embodied in the National Doctrine of Educational Development in the 21st Century, where it is stated that further "progress of society is no longer possible" human progress (Natsionalna doktryna rozvytku osvity u XXI stolitti: Proekt, 2001, 4), in the Law of Ukraine "On Education", in which the task of "comprehensive development of a person as a person and the highest value of society" stands next to the tasks of enriching the "intellectual, creative, cultural potential of the people" and "providing the economy with qualified specialists" (Zakon Ukrainy «Pro osvitu», 2017, 3), as well as in the State National Program "Education. Ukraine of the XXI Century", which emphasizes that education should be aimed at the formation of "developed spirituality, physical perfection, moral, artistic, aesthetic, legal, labor, ecological culture" (Derzhavna natsionalna prohrama «Osvita. Ukraina XXI stolittia», 1994, 15).

Discussing the problem of providing and evaluating the quality of education, leading national and foreign scientists agree that at the present stage of higher professional school development, it is not enough to consider as a system of knowledge, abilities and skills only. Thus, B. Hershunskyi called obligatory additional indicators of the quality of education as a graduate mentality and his/her desire for self-realization in life (Hershunskyi, B. 1998). M. Potashnyk in the scientific work 
"Management of the quality of education" notes that in the analysis of the quality of education V. Zahviazinskyi proposes to take into account the indicators of personal development of the student (Potashnyk, M. 2000, 71-80), and V. Karakovskyi - self-awareness, moral health , education, active citizenship, etc. (Potashnyk, M. 2000, 81-84). This, according to M. Potashnyk, indicates the urgent need to "strengthen the educational and educational component of education and the need to include indicators of personal development and morality / moral upbringing in education standards" (Potashnyk, M. 2000, 85). But the complexity of determining the level of formation of these indicators still hinders their widespread use as quality criteria for higher professional education.

We believe that in the context of Ukraine's integration into the European and global educational space, at present there is a contradiction between the objective need for the preparation of modern highly qualified and highly spiritual specialists of engineering-technical profile and the lack of development of this scientific pedagogical problem, which negatively affects the practical activity of all of the educational process of the technical higher educational institution, on the effectiveness of its work in the training of competitive young professionals. In our opinion, this contradiction can be solved by affirming the task of forming a professional culture in students as an integral characteristic of the future specialist's personality among the tasks of a holistic pedagogical process in higher education institutions.

Studying the traditional and specific in the interconnection of education and culture, R. Pozinkevych emphasizes that "the educational system must reach new historical boundaries" (Pozinkevych, R. 2000, 3-4), and considers the appeal of modern scientific pedagogical thought to versatile analysis of historical educational models and their evolution by evidence of intensive search for "cultural-educational" and "cultural-educational" ways of modern education out of crisis (Pozinkevych, R. 2000, 322). I. Ziaziun and H. Sahach argue that at the turn of the century was born "cultural and creative education with its conception of a humanistic type of personality, which not only consumes cultural values, but also multiplies them, personality as an endowment and purpose, but not a means of social development" (Ziaziun, I.; Sahach, H. 1997, 40).

The complexity and versatility of the term "culture" itself results in a large number of classifications of that concept based on different principles. The analysis of reference literature on philosophy, political science and sociology makes it possible to name the following among the most common approaches to considering the concept of "culture":

1) According to a certain historical epoch (when it comes to ancient culture, culture of the ancient world, medieval culture, modern culture, etc.);

2) According to ethno-national and geographical-regional features (culture of the West, East, American culture, Slavic culture, Ukrainian, German culture, etc.);

3) According to the sphere of human being (distinguish material culture, spiritual culture, religious culture, worldview, national, civil, political, moral, artistic, physical, mental, aesthetic, musical, etc.);

4) According to the sphere of manifestation of human activity (different industrial culture, professional, culture of work, leisure, consumption, everyday life, service, communication, language, behavior, feelings, thinking);

5) According to the grounds of social groups and segments of the population (culture of the collective, person, individual, class (peasant, bourgeois culture), society; as well as youth, military, artistic, pedagogical culture, etc.) (Isaienko, S. 2009).

Recognizing that due to the complexity of the cultural category, any definition does not cover all its sides, however, it should be noted that most researchers of this phenomenon use one or more approaches in their scientific analysis, most often typological, value, activity, or personal. Consistent with the approaches proposed by scientists to consider the professional culture of a specialist, we consider it necessary to emphasize that for a holistic understanding of culture (and professional culture in particular), each of the components of culture is important for the above approaches, since values, activities, and qualities of personality are not they deny but complement each other.

The analysis of the concepts of humanitarian in higher education and the practice of teaching the disciplines of the humanitarian cycle indicates the existence of significant contradictions, which 
only confirms the relevance of this research. Contrary to the trends of the global educational space, the content of humanitarian subjects is not yet sufficiently integrated into a coherent system of personality- and culture-oriented higher education. There is a contradiction between the enormous potential of the content of the humanities, which reflects the multiplicity of worldviews, dialogicality as a style of thinking, the integrity of knowing a person himself and, on the other hand, the representation of these subject areas as a general "appendage" of special disciplines. The information-explanatory approach that prevails in the educational space of the institution of higher education does not provide for the students to turn to the value-semantic basis of the received humanitarian knowledge, practically does not actualize the processes of search for meaning, choice, reflection, evaluation. When transmitting a huge amount of information, teachers often rely only on the capacity of memory, perception, attention of students who do not realize the potential of valueoriented activities.

In addition, the modern theory of personality-oriented education, activity and cultural approaches are still insufficiently mastered by teachers of higher education, which negatively affects the creation and application of technologies for the development of personal experience of future professionals. That is why one of the most important tasks of higher education in the context of Ukraine's integration into the global educational space is the formation in a future specialist of a valuable attitude towards the humanitarian component of professional training at both the cognitive and real-behavioral levels.

Taking into account the breadth of material on this issue, we have limited the scope of the study to the discipline of "Foreign Language for Specific Purposes". Having a communicative orientation and two-way communication with both public and specialized disciplines, foreign language as a general subject is at the intersection of humanities and special subjects (Hurinchuk, S.; Isaienko, S. 2018). The conducted analysis of the criteria and indicators of foreign language proficiency made it possible to conclude that learning a foreign language is aimed not only at the formation of linguistic (lexical and grammar) and speech competences, but also the development of a personality integrated into the world culture, science, art, which has a special type humanistic outlook, ethnic tolerance, openness to other cultures. Person-oriented model of education opens up new opportunities for designing the process of personal development of the future specialist and allows reviewing the goals, content and technologies of teaching the humanities in a higher educational establishment.

As a result of the research, we can state that 1) the formation of students' value attitude to the humanitarian component of professional education is facilitated by the inclusion in the content of foreign language teaching components, focused on the development of the value-sense sphere of personality of future professionals; 2) the content of disciplines of the humanitarian cycle should contain the basic values of humanitarian knowledge (spiritual, moral, semantic universals); 3 ) as a technology for creating a situation of humanitarian-oriented consciousness of the personality of a specialist, it is necessary to use educational tasks-situations with different developing functions and "dialogical" form of educational interaction. The development of a foreign language competence should be considered as another core of the professional training process, as it is now a professionally required competence and one of the conditions for the development of humanitarian consciousness.

Conclusions. Until now, the level of education of a specialist has been defined (and often still is defined) mainly by knowledge of the natural sciences. In our view, the qualitative training of engineering staff cannot be limited to the purely technical cycle of subjects. Living and modern manufacturing requires the engineer to have knowledge of the social sciences and humanities, knowledge of related fields of engineering, computer technology, as well as mastery of the native language and foreign language skills.

The educational process of the vast majority of higher education institutions is dominated by traditional technology of transfer and assimilation of knowledge, and emphasis is placed on mastering a large amount of educational material. As a result, students are convinced that any problem has only one way to solve it and there are no alternative ways to solve it. However, the current conditions of development of Ukrainian society determine the need to revise such a methodology of professional education. Along with the knowledge and skills that are sufficient to 
fulfill the basic professional functions, necessary and those that would provide the opportunity for professional development of a specialist related to his/her promotion in the positions; development of new equipment and technologies without changing the place of work; changes in production profile; making moral decisions in extreme situations where a specialist is forced to go beyond the scope of his/her duties; correct assessment of their professional activity in the system of work responsibilities together with other people, interaction with them in the process of regulating their and their activities.

Thus, since becoming an engineering and technical specialist must be accompanied by the development of his/her personal qualities, and the specialist-professional must be able to adapt quickly and painlessly to the changing conditions of economy and production, in the organization of training of future specialists in the walls of a higher education institution - a certain shift of focus is needed educational process on the problem of formation of competencies of the future specialist for the development of his/her potential inclinations in the chosen direction of professional training.

The conducted analysis does not exhaust all aspects of the problem, and therefore further research is envisaged in a comprehensive study of the historical aspect of the essence, directions of reforming the higher education system of Ukraine, implementation of the principles of humanization and humanitarization in higher education institutions and in the development of ways of effectively forming a valuable attitude of students to humanities.

\section{ЛІТЕРАТУРА}

1. Hurinchuk, S.; Isaienko, S. (2018). Culture formation as a significant component in specialists' training. Scientific Light, Vol. 1, № 16. P. 18-21.

2. Андрущенко, В. (2012). «Філософське самовбивство» останніх радянських гуманітаріїв. Філософія освіти, № 1-2 (11). С. 7-15.

3. Габович, О. (2001). Гуманітаризація науки чи їі криза? Вісник Національної академії наук України, № 7. С. 54-61.

4. Гершунский, Б. (1998). Философия образования для XXI века (в поисках практикоориентированных образовательных концепций). Москва: Совершенство. 608 с.

5. Гончаренко, С. (1995). I все таки - гуманітаризація. Педагогіка і психологія, № 1. С. 37.

6. Державна національна програма «Освіта. Україна XXI століття». (1994). Київ: Райдуга. $61 \mathrm{c.}$

7. Добрускин, М. (2000). Концептуальные основы гуманизации и гуманитаризации высшего технического образования. Гуманізація $і$ гуманітаризація вищої технічної освіти. Збірник наукових праць. Всеукраїнська науково-методична конферениія, Харків. С. 5-6.

8. Закон України «Про освіту». (2017). Відомості Верховної Ради, № 38-39, ст.380.

9. Зязюн, І.; Сагач, Г. (1997). Краса педагогічної дії. Київ. 302 с.

10. Ісаєнко, С. (2009). Формування професійної культури у студентів інженерно-технічних спеціальностей засобами іноземної мови: автореф. дис. на здоб. наук. ступ. канд. пед. наук: 13.00.04 - теорія і методика професійної освіти. Київ, ІВО НАПНУ. 20 с.

11. Кургузов, В. (1997). Гуманитарная среда технического вуза (Методология. Опыт. Проблемы.), Улан-Удэ. 84 с.

12. Національна доктрина розвитку освіти у XXI столітті: Проект. (2001). Педагогічна газета, № 7. C. 4-6.

13. Парижный, Ю. (1992). О сущности гуманизации и гуманитаризации. Гуманізаиія $i$ гуманітаризація - пріоритетний напрямок державної політики в галузі вищої освіти. Дніпропетровськ: Дніпр. державний інститут. Гуманітарний центр. 134 с.

14. Позінкевич, Р. (2000). Освіта в системі культури: Монографія. Луцьк: Ред.-вид. від. «Вежа» Волин. держ. ун-ту ім. Лесі Українки. 348 с.

15. Поташник, М. (2000). Управление качеством образования. Москва. 448 с.

16. Савельев, А. (2001). Высшее образование: состояние и проблемы развития. Москва: НИИВО. 120 с. 
17. Скляр, П.; Уманська, Т. (2007). «Гуманізація» та «Гуманітаризація»: поняття, співвідношення та шляхи впровадження в освіту. Вісник Національного технічного університету Украйни «Київський політехнічний інститут». Філософія. Психологія. Педагогіка, № 1. Retrieved from: http://www.nbuv.gov.ua/portal/soc_gum/VKPI_fpp/20071/index.html.

18. Чистовська, I. (2008). Гуманізація та гуманітаризація навчально-виховного процесу у вищих технічних навчальних закладах. Вісник національного технічного університету Украйни «Київський політехнічний інститут» : Філософія. Психологія. Педагогіка, №1. C. 191-195.

\section{REFERENCES}

1. Hurinchuk, S.; Isaienko, S. (2018). Culture formation as a significant component in specialists' training. Scientific Light, Vol. 1, № 16. P. 18-21.

2. Andrushchenko, V. (2012). «Filosofske samovbyvstvo» ostannikh radianskykh humanitariiv ["The philosophical suicide" of the last Soviet humanities]. Filosofiia osvity - Philosophy of education, № 1-2 (11). S. 7-15. [in Ukrainian]

3. Habovych, O. (2001). Humanitaryzatsiia nauky chy ii kryza? [The humanization of science or its crisis?]. Visnyk Natsionalnoi akademii nauk Ukrainy - Bulletin of the National Academy of Sciences of Ukraine, № 7. S. 54-61. [in Ukrainian]

4. Hershunskyi, B. (1998). Fylosofiya obrazovaniya dlia XXI veka (v poyskakh praktykooryentyrovannykh obrazovatelnykh kontseptsyi) [The philosophy of education for the 21st century (in search of practice-oriented educational concepts)]. Moskva: Sovershenstvo. $608 \mathrm{~s}$. [in Russian]

5. Honcharenko, S. (1995). I vse taky - humanitaryzatsiia [But all the same humanitarization]. Pedahohika i psykholohiia - Pedagogy and Psychology, № 1. S. 3-7. [in Ukrainian]

6. Derzhavna natsionalna prohrama «Osvita. Ukraina XXI stolittia» [The State National Program "Osvita. Ukraine of the XXI century"]. (1994). Kyiv: Raiduha. 61 s. [in Ukrainian]

7. Dobruskyn, M. (2000). Kontseptualnye osnovy humanyzatsyy y humanytaryzatsyy vyssheho tekhnycheskoho obrazovanyia [Conceptual foundations of the humanization and humanitarization of higher technical education]. Humanizatsiia $i$ humanitaryzatsiia vyshchoi tekhnichnoi osvity. Zbirnyk naukovykh prats. Vseukrainska naukovo-metodychna konferentsiia, Kharkiv - Humanization and humanitarization of higher technical education. Collection of scientific works. All-Ukrainian scientific and methodological conference. S. 56. [in Russian]

8. Zakon Ukrainy "Pro osvitu» [Law of Ukraine "On Education"]. (2017). Vidomosti Verkhovnoi Rady - Bulletin of the Verkhovna Rada, № 38-39, st.380. [in Ukrainian]

9. Ziaziun, I.; Sahach, H. (1997). Krasa pedahohichnoi dii [The beauty of pedagogical action]. Kyiv. 302 s. [in Ukrainian]

10. Isaienko, S. (2009). Formuvannia profesiinoi kultury u studentiv inzhenerno-tekhnichnykh spetsialnostei zasobamy inozemnoi movy: avtoref. dys. na zdob. nauk. stup. kand. ped. nauk: 13.00.04 - teoriia i metodyka profesiinoi osvity [Formation of professional culture in students of engineering and technical specialties by means of a foreign language: author. diss. on $\mathrm{PhD}$ degree in Pedagogy. Sciences: 13.00.04 - Theory and methodology of professional training]. Kyiv, IVO NAPNU. 20 s. [in Ukrainian]

11. Kurhuzov, V. (1997). Humanytarnaia sreda tekhnycheskoho vuza (Metodolohyia. Opyt. Problemy) [The humanitarian environment of a technical university (Methodology. Experience. Problems.)], Ulan-Ude. 84 s. [in Russian]

12. Natsionalna doktryna rozvytku osvity u XXI stolitti: Proekt [The National Doctrine of Educational Development in the 21st Century: The Project]. (2001). Pedahohichna hazetaPedagogical newspaper, № 7. S. 4-6. [in Ukrainian]

13. Paryzhnyi, Yu. (1992). O sushchnosty humanyzatsyy y humanytaryzatsyy [On the essence of humanization and humanitarization]. Humanizatsiia $i$ humanitaryzatsiia - priorytetnyi 
napriamok derzhavnoi polityky $v$ haluzi vyshchoi osvity - Humanization and humanitarization - a priority area of public policy in the field of higher education. Dnipropetrovsk: Dnipr. derzhavnyi instytut. Humanitarnyi tsentr. 134 s. [in Russian]

14. Pozinkevych, R. (2000). Osvita v systemi kultury: Monohrafiia [Education in the system of culture: Monograph]. Lutsk: Red.-vyd. vid. «Vezha» Volyn. derzh. un-tu im. Lesi Ukrainky. 348 s. [in Ukrainian]

15. Potashnyk, M. (2000). Upravlenye kachestvom obrazovanyia [Management of the quality of education]. Moskva. 448 s. [in Russian]

16. Savelev, A. (2001). Vysshee obrazovanye: sostoianye y problemy razvytyia [Higher education: state and development problems]. Moskva: NYYVO. 120 s. [in Russian]

17. Skliar, P.; Umanska, T. (2007). «Humanizatsiia» ta «humanitaryzatsiia»: poniattia, spivvidnoshennia ta shliakhy vprovadzhennia $\mathrm{v}$ osvitu ["Humanization" and "humanitarization": concepts, relationships and ways of implementation in education]. Visnyk Natsionalnoho tekhnichnoho universytetu Ukrainy "Kyivskyi politekhnichnyi instytut». Filosofiia. Psykholohiia. Pedahohika - Bulletin of the National Technical University of Ukraine "Kyiv Polytechnic Institute". Philosophy. Psychology. Pedagogy, № 1. Retrieved from: http://www.nbuv.gov.ua/portal/soc_gum/VKPI_fpp/2007-1/index.html. [in Ukrainian]

18. Chystovska, I. (2008). Humanizatsiia ta humanitaryzatsiia navchalno-vykhovnoho protsesu u vyshchykh tekhnichnykh navchalnykh zakladakh [Humanization and humanitarization of educational process in higher technical educational establishments]. Visnyk natsionalnoho tekhnichnoho universytetu Ukrainy «Kyivskyi politekhnichnyi instytut» : Filosofiia. Psykholohiia. Pedahohika - Bulletin of the National Technical University of Ukraine "Kyiv Polytechnic Institute". Philosophy. Psychology. Pedagogy, №1. S. 191-195. [in Ukrainian]

Ісаснко С.А., Гурінчук С.В.

ФОРМУВАННЯ ЦІНІСНОГО СТАВЛЕННЯ ДО ГУМАНІТАРНОГО
КОМПОНЕНТУ ПРОФЕСІЙНОЇ ПІДГОТОВКИ ЯК ЗАВДАННЯ ВИЩОЇ ОСВІТИ У
КОНТЕКСТІ ІНТЕГРАЦЇ̈ УКРАЇНИ ДО СВІТОВОГО ОСВІТНЬОГО ПРОСТОРУ

Питання формування професіонала, особливості прояву людської особистості в ї професійній діяльності, взаємозв'язок та взаємозалежність життєдіяльності людини та сфери ї̈ професійної діяльності надзвичайно актуальні у XXI столітті. $У$ статті аналізується проблема формування иіннісного ставлення студентів до гуманітарного компоненту професійної підготовки та професійної культури особистості майбутніх фахівців інженерно-технічного профілю на сучасному етапі розвитку вищої професійної освіти України у контексті ї̈ інтеграції до світового освітнього простору. У кінці XX століття стало звичним уважати чи не єдиною функиією технічної освіти - підготовку фахівия, здатного виконувати конкретні виробничі задачі. Проте, сучасне виробництво вимагає від інженерно-технічних фахівців виконання функцій нетипових у минулому, потребує переосмислення багатьох колишніх і створення нових світоглядних орієнтирів $i$ цінностей, без яких неможливе відродження та існування суспільства. Якісна підготовка інженерно-технічних прачівників не може обмежуватись суто технічним ииклом навчальних предметів. Життя і сучасне виробництво вимагає від інженера знань із сочіально-гуманітарних предметів, знань із суміжних із інженерно-технічною підготовкою сфер, комп'ютерних технологій, а також володіння рідною мовою і знання іноземних мов. Автори вважають, щьо одним із головних завдань системи вищої освіти є иілеспрямована робота по формуванню професійної культури майбутніх фахівців, а формування ијіннісного ставлення до гуманітарних аспектів життя та професійної діяльності є складовою зазначеної культури. Однак, професійна культура - складне багатобічне утворення, формування якого починаються на університетській лаві і продовжується протягом усього життя. У рамках професійної підготовки у закладі вищої освіти можна вести мову лише про закладання підвалин, основ такого особистісного утворення. Відтак, необхідність формування нового сочіального середовища, розробки таких пріоритетів суспільного розвитку, де головним елементом $є$ сама людина, стали сьогодні очевидними $i$ загальновизнаними у світі. 
Ключові слова: ціннісне ставлення, гуманітарний компонент професійної підготовки, професійна культура фахівия, діяльнісний, аксіологічний та культурологічний підходи, особистісно-орієнтована модель вищої освіти, професійна підготовка

Исаенко С.А., Гуринчук С.В.

ФОРМИРОВАНИЕ ЦЕННОСТНОГО ОТНОШЕНИЯ К ГУМАНИТАРНОМУ КОМПОНЕНТУ ПРОФЕССИОНАЛЬНОЙ ПОДГОТОВКИ КАК ЗАДАЧА ВЫСШЕГО ОБРАЗОВАНИЯ В КОНТЕКСТЕ ИНТЕГРАЦИИ УКРАИНЫ В МИРОВОЕ ОБРАЗОВАТЕЛЬНОЕ ПРОСТРАНСТВО

Вопросы формирования профессионала, особенности проявления человеческой личности в ее профессиональной деятельности, взаимосвязь и взаимозависимость жизнедеятельности человека и сферы его профессиональной деятельности чрезвычайно актуальны в XXI веке. $B$ статье анализируется проблема формирования иенностного отношения студентов $\kappa$ гуманитарному компоненту профессиональной подготовки и профессиональной культуры личности будущих специалистов инженерно-технического профиля на современном этапе развития выстего профессионального образования Украины в контексте ее интеграции в мировое образовательное пространство. В коние XX века стало привычным считать едва ли не единственной функиией технического образования - подготовку специиалиста, способного выполнять конкретные производственные задачи. Однако, современное производство требует от инженерно-технических специалистов выполнения функиий нетипичных в прошлом, требует переосмысления многих бывших и создание новых мировоззренческих ориентиров и ценностей, без которых невозможно возрождение $u$ существования общества. Качественная подготовка инженерно-технических работников не может ограничиваться чисто техническим циклом учебных предметов. Жизнь и современное производство требует от инженера знаний по сочиально-гуманитарным предметам, знаний из смежных с инженерно-технической подготовкой сфер, компьютерных технологий, а также владения родным языком и знания иностранных языков. Авторы считают, что одной из главных задач системы выстего образования является иеленаправленная работа по формированию профессиональной культуры будущих специалистов, а формирование ценностного отномения к гуманитарным аспектам жизни и профессиональной деятельности является составной указанной культуры. Однако, профессиональная культура - сложное многостороннее образование, формирование которого начинается на университетской скамье и продолжается в течение всей жизни. $B$ рамках профессиональной подготовки в учреждении высшего образования можно говорить только о закладке фундамента, основ такого личностного образования. Следовательно, необходимость формирования новой сочиальной среде, разработки таких приоритетов общественного развития, где главным элементом является сам человек, стали сегодня очевидными и общепризнанными в мире.

Ключевые слова: иенностное отношение, гуманитарный компонент профессиональной подготовки, профессиональная культура специалиста, деятельностный, аксиологический и культурологический подходы, личностно-ориентированная модель высшего образования, профессиональная подготовка 